[ C H A P T E R T T O ]

\title{
LOCKE'S
}

\section{DIVINE POLITICS}

I wish here to sketch and probe the social-contract arguments (I think there are three) in Locke's Second Treatise. In doing so, I will attempt to reconstruct Locke's moral theory. ("True politics," remarked Locke in 1697 , "I look on as a part of moral philosophy.") Such a reconstruction will allow full comprehension of the limits of Locke's contract arguments. I close by showing that while Locke has the makings of a plausible resolution of the Euthyphro dilemma, his moral theory fails to fill out or support his political theory.

Throughout the chapter I cite from the following works by John Locke: $E d u$ cation (Some Thoughts Concerning Education, in The Educational Writings of Jobn Locke, ed. James L. Axtell [Cambridge: Cambridge University Press, I968]); Essay (An Essay concerning Human Understanding, ed. Peter H. Nidditch, Clarendon ed. [Oxford: Clarendon, 1979]); Law (Essays on the Law of Nature, ed. and trans. W. von Leyden [Oxford: Clarendon, 1954]); Letter (Epistola de Tolerantia: A Letter on Toleration, ed. Raymond Klibansky and trans. J. W. Gough [Oxford: Clarendon, 1968]); Tracts (Two Tracts on Government, ed. Philip Abrams [Cambridge: Cambridge University Press, 1967]); Treatises (Two Treatises of Government, ed. Peter Laslett, 2d ed. [Cambridge: Cambridge University Press, 1970]; in the notes, roman numerals I and II following Tracts and Treatises refer to the number of the tract or treatise); Reasonableness (The Reasonableness of Cbristianity, in Works VII); Works (The Works of Jobn Locke, Io vols. [London, 1 823]). Author's italics throughout, unless otherwise noted.

"Locke's Draft Letter to the Countess of Peterborough," in Axtell, Educational Writings of Jobn Locke, p. 395. As the Clarendon edition of Locke's works being prepared by Oxford University Press is emerging with glacial speed, I will quote from whatever seems the best edition available for each work. 


\section{Three Contract Arguments}

"To understand Political Power right, and derive it from its Original," says Locke, "we must consider what State all Men are naturally in," so setting out his plan of attack for the Second Treatise. ${ }^{2}$ Locke tells us that "Men living together according to reason, without a common Superior on Earth, with Authority to judge between them, is properly the State of Nature." It isn't clear whether Locke means to make a substantial observation about what state we are "naturally" in or to offer a stipulative definition of state of nature; but for my purposes nothing hangs on the difference. He will investigate what society would be like without politics in order to understand politics.

To offer a quick review of the state of nature: People there are governed by a law of nature, "plain and intelligible to all rational Creatures," however shrouded in mystery it might seem to the reader. Perhaps aware of the mystery, Locke demurs, "Though it would be besides my present purpose, to enter here into the particulars of the Law of Nature, or its measures of punishment, yet, it is certain there is such a Law, and that too, as intelligible and plain to a rational Creature, and a Studier of that Law, as the positive laws of Commonwealths, nay possibly plainer." ${ }^{4}$ One particular of the law of nature-indeed, the "Fundamental Law" - we do find out: "As much as may be, all the Members of the Society are to be preserved."s And we are treated to a fleeting glimpse of the internal workings of the law of nature: "Men being all the Workmanship of one Omnipotent, and infinitely wise Maker; All the Servants of One Sovereign Master, sent into the World by his order and about his business, they are his Property, whose Workmanship they are, made to last during his, not one anothers Pleasure."6

${ }^{2}$ Treatises II $\S_{4}$ p. 287 . Locke believed that there is "a Foundation in Nature" for subjecting women to men (I $\$ 47$ p. I92; see too II $\$ 82$ p. 339), and, perhaps accordingly, he generally talks about men. I reluctantly follow him here.

${ }^{3}$ Treatises II § I9 p. 298 ; see too Treatises II $\$ 4$ p. 287.

+Treatises II § I 24 p. 369, II §I 2 p. 293.

${ }^{5}$ Treatises II $\S_{1} 59$ p. 393 ; see too Treatises II $\S_{16}$ pp. 296-297, II $\S_{1} 34$ pp. 373-374, II § I 83 p. 409; Education, p. 226.

${ }^{6}$ Treatises II $\$ 6$ p. 289. 


\section{WITHOUT FOUNDATIONS}

I will try later to extend that glimpse, but now I want to dispose of an apparent blatant inconsistency on Locke's part. Locke appeals to God's ownership of us to explain why we may not commit suicide, why we must not harm each other, and why we may not contract ourselves into slavery. ${ }^{7}$ Yet he defends private property rights by suggesting that we gain such rights by mixing our labor with unowned objects or land. That suggestion hangs in turn on our ownership of ourselves: "Every Man," he asserts, "has a Property in his own Person." we own ourselves. Is Locke incoherent?

I think not. In each of the passages in the Treatises where Locke says we own ourselves, he says we own our persons; when he speaks of God's ownership, he says God owns us as men. Here, it might seem, is a niggling philosophical distinction; but it is one Locke uses, and it is perfectly serviceable. In the Essay concerning Human Understanding, Locke constructs some strikingly modern puzzle cases in his attempt to work out a theory of personal identity. One of those cases is much to the point: "For should the Soul of a Prince, carrying with it the consciousness of the Prince's past life, enter and inform the Body of a Cobler as soon as deserted by his own Soul, every one sees, he would be the same Person with the Prince, accountable only for the Prince's Actions: But who would say it was the same Man?" Locke realizes that his readers may initially frown at the distinction ("I know that in the ordinary way of speaking, the same Person, and the same Man, stand for one and the same thing"10), but he thinks it necessary to make it.

Locke contends that person is "a Forensick Term," both in the Essay and in his veiled "Defence of Mr. Locke's Opinion Concerning Personal Identity." We hold people responsible for

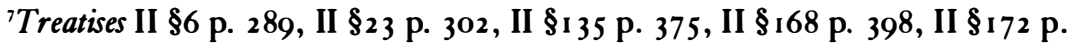
400.

${ }^{8}$ Treatises II $\S_{27}$ p. 305 ; also Treatises II $\S_{44}$ P. 3 I6, II $\S_{1} 73$ p. 40 I, II § I 90 pp. 4II-4I 2.

${ }^{9}$ Essay, p. 340.

${ }^{10}$ Essay, p. 340.

"Essay, p. 346; John Locke, "Defence," in Works III: I 79-20 I . Locke distinguishes person from body in Works IV:303-334, in arguing that the dead's resurrection need not include their bodies. 
their actions; we blame and praise; we do so, in Locke's view, precisely insofar as and because they are the same persons. Persons, therefore, we may take as moral agents, and men as bodies, despite Locke's hesitance on the latter point. ${ }^{12}$ God, then, owns us as physical organisms. ${ }^{13}$ We may not harm each other, or kill ourselves, because that would be infringing on God's property rights. So Locke typically limits himself to enjoining the preservation of all, to forbidding harm (though he does aver, harshly enough, "I think it every Man's indispensible Duty, to do all the Service he can to his Country: And I see not what Difference he puts between himself and his Cattel, who lives without that Thought"14).

A bit more puzzling, but not nonsensical, is the claim that we own ourselves as moral agents. ${ }^{15}$ I take Locke to mean that we act freely, not just as God's automatons, and that we are responsible for our actions. Locke insists on such freedom of action, though he discards free will as an absurd phrase and admits that he cannot reconcile human freedom with God: "I cannot make freedom in man consistent with omnipotence and omniscience in God, though I am as carefully persuaded of both, as of any truths I most firmly assent to. And, therefore, I have long since given off the consideration of that question, resolving all into this short conclusion, that if it be possible for God to make a free agent, then man is free, though I see not the way of it." ${ }_{16}$ The

${ }^{12}$ Essay, p. 343. I take Locke's considered view to be like the second advanced on p. 348: "But if to any one the Idea of a Man be, but the vital union of Parts in a certain shape." "Man" must at least include body, else the prince/cobbler puzzle would be no puzzle at all.

${ }^{13}$ Locke, then, cannot be enlisted as a bourgeois ideologist trying to rationalize the quirky claim that laborers own their bodies. Compare Robert Paul Wolff, "A Critique and Reinterpretation of Marx's Labor Theory of Value," Pbilosopby \& Public Affairs Io (Spring 1981): 1 Io.

${ }^{14}$ Education, p. I I I. Locke's italics removed. Locke regularly demotes the immoral to the status of brutes: see for example Treatises II § IO p. 29 I, II § I I p. 292.

'Compare J. P. Day, “Locke on Property," Pbilosophical Quarterly i 6 (July 1966): 207-2 20, reprinted in Life, Liberty, and Property: Essays on Locke's Political Ideas, ed. Gordon J. Schochet (Belmont, Calif.: Wadsworth, I97 I).

${ }^{16}$ Locke to Molyneux, 20 jan I692-3, in Works IX:305; also Works IV:492. Locke grapples with free will and determinism in the Essay, pp. 233-27 I, and discards "free will" at p. 240. Compare C. B. Macpherson, The Political Theory of 
law of nature commands our preservation because God owns our bodies, and it commands the protection of property rights because we own ourselves. Our owning our labor, and so our gaining property rights in unowned things we mix our labor with, pose additional problems I leave aside. I mean only to acquit Locke of the charge of gross inconsistency.

Let us then return to our story. Locke's anarchy (for that is what his state of nature is) is none too pleasant, and it worsens as Locke considers it. Although people have substantial interests in safeguarding "their Lives, Liberties, and Estates, which," Locke tells us, "I call by the general name, Property," those interests are left insecure. True, the law of nature dictates the preservation of property. But problems arise where everyone is entitled to enforce the law. People are partial in considering their own cases ("'tis easily to be imagined," Locke puckishly observes, "that he who was so unjust as to do his Brother an Injury, will scarce be so just as to condemn himself for it"), and many do not even take the trouble to learn the law. Also, since the unjust may be stronger than the just, even deserved sentences may go unenforced. So men are forced to form a government, or as Locke says are "driven into Society." ${ }_{18}$ Locke generally refers to the contract as forming the society, and he has the society go on to entrust a government with the business of politics. He also says, though, that by the law of nature "Mankind are one Community, make up one Society distinct from all other Creatures"; and, of course, the state of nature boasts extensive social relations, indeed, all but political ones. It is the formation of a "particular Political Society" Locke takes as decisive in terminating the state of nature. ${ }^{19}$ Nothing for my purposes hangs on the re-

Possessive Individualism (Oxford: Clarendon, I 962), p. 23 I. Compare too Treatises II $\$ 63$ p. 327.

"Treatises II $\S$ I 23 p. 368 . I take this extended use of property as typical in the Treatises, and adopt it myself here. Laslett has a helpful list of references on Locke's use of property on p. $34 \mathrm{In}$.

${ }^{18}$ Treatises II $\S_{\text {I }} 3$ p. 294, II § I 24 p. 369; Treatises II $\S_{1} 26$ p. 369; Treatises II \$I 27 p. 370.

${ }^{19}$ Treatises II I $_{2} 8$ p. 370 . Note too Treatises II $\$ 89$ p. 343: "the Society, or which is all one, the Legislative thereof." Locke prefers "compact" and "consent" locutions to "contract," generally reserving the lattermost for marriage; 


\section{LOCKE'S DFVINE POLITICS}

sultant partitioning of humankind into independent political units. Accordingly, here I cast the contract as one to establish a government.

The terms of Locke's contract are familiar enough. People entrust a state with the protection of property. The state's authority is drastically limited. Though it does have a power of prerogative to advance the public good "without the prescription of the Law, and sometimes even against it," it appears more typically as "Umpire," ruling "by settled standing Rules, indifferent, and the same to all Parties." ${ }^{20}$ Its exceeding its boundaries represents a violation of the trust, and may in fact be ground for revolution. The state's rights are no wondrous emergent properties created by the concord of individuals: each individual has simply transferred to the executive his power of enforcing the law of nature, to the legislature his power of doing "whatsoever he thinks fit for the preservation of himself and others within the permission of the Law of Nature." 21 The law of nature, then, lives on in political society. ${ }^{22}$

All this is fair enough, but we need an account of the status of the contract. ${ }^{23}$ Is it a historical event? a metaphor describing how each of us comes to fall under the dominion of the state? a purely hypothetical construct about timeless truths of politics? We need too an account of the uses to which the contract is to be put. Is it a tool in the never-ending polemic against Filmer? a prop for a theory of obligation? for a theory of legitimacy? It is, I want to suggest, all these things, and serves all these functions. I will proceed by sketching out, in idealized form, the three uses

though see Treatises I $\$ 96$ p. 230 , where "Contract" is equated with "Consent of the People."

${ }^{20}$ Treatises II $\S$ I6o p. 393; Treatises II $\S 87$ p. 342. Also Treatises II $\$ 2$ I 2 p. 425 , II $\$ 227$ p. 434 .

${ }^{21}$ Treatises II § I 28 p. 370.

${ }^{22}$ Treatises II §1 35 p. 376.

${ }^{23} \mathrm{My}$ reading of Locke for the rest of this section has been greatly influenced by Hanna Pitkin, "Obligation and Consent," American Political Science Review 59 (December 1965): 990-999, and 60 (March 1966): 39-56, reprinted in Pbilosopby, Politics and Society, ed. Peter Laslett, W. G. Runciman, and Quentin Skinner, 4th ser. (London: Basil Blackwell, 1972). My departures from her view should be readily apparent. 
for the contract, and then moving closer to Locke's text and exploring some muddy spots.

Locke is clear that we are to understand the contract as a report on our ancestors' behavior. Consider what he has to say about the objection "That there are no Instances to be found in Story of a Company of Men independent and equal one amongst another, that met together, and in this way began and set up a Government." ${ }^{24} \mathrm{He}$ argues that we cannot fairly expect records of this sort of contract, struck after all in very early times, to have survived; and he adduces "evident matter of fact," regaling the reader with instances of the formation of government by contract. Rome and Venice were founded "by the uniting together of several Men free and independent one of another"; "if Josephus Acosta's word may be taken," Peru, Florida, the Cheriquanas, and "Bresil" offer still more examples; and finally those who left Sparta with Palantus presumably established a government by contract. ${ }^{25}$ The social contract, then, is not just a plausible story about the inception of political society; it actually happened.

At the point in the Treatises at which Locke launches into this reading of history, he has already announced that "every Man's Cbildren being by Nature as free as himself, or any of his Ancestors ever were, may, whilst they are in that Freedom, choose what Society they will join themselves to, what Commonwealth they will put themselves under." 26 If history provides us with no source of obligation, why is he troubling us with crumbled, yellowing tales of antiquity? Locke appeals to history for one of his favorite activities in the Treatises: ridiculing Sir Robert Filmer's theories. Filmer's case, as set forth in Patriarcha, hinges on the claim that political authority has descended from Adam. Locke, then, can refute Filmer by showing that Filmer's history is wrong. Here is why the historical narrative winds on, leaving the reader dizzied with chronicles of America, Peru, Mexico, the American Indians, Israel, Jephtha, the Ammonites, the Gileadites, Jotham, the Shechemites, Gideon, Midian, Abimelech, Samuel, the Philistines, Saul, Mispah, David, and Hebron:

${ }^{24}$ Treatises II $\S 100$ p. $35 \mathrm{I}$.

${ }^{25}$ Treatises II §1 02 p. $35^{2}$; Treatises II $\S 102$ p. 353 , II $\S 103$ p. 353.

${ }^{26}$ Treatises II $\$ 73 \mathrm{P} \cdot 333$. 


\section{LOCKE'S DIVINE POLITICS}

Locke wants to show where Filmer has gone wrong in his reading of history. ${ }^{27}$

So the historic contract plays a purely negative role in the argument. It is surprising, then, that Hume spent so much time arguing that "force . . . is the origin of almost all the new [governments] which were ever established in the world." Perhaps he had in mind followers of Locke's contract doctrine, not "the most noted of its partisans," the champion of "so refined and philosophical a system." ${ }^{28}$ It is surprising too that Josiah Tucker scornfully called "upon the Lockians once more [each to answer separately for him or herself] to name the Year, Month, Week, Day, or Hour, when this Contract was made between the Government of Great-Britain on the one part, and A.B. or C.D. or E.F., on the other," and so strenuously insisted that "the true basis of civil government," as against these weirdly historicist "Lockians," was a "quasi-contract," one that bears a striking resemblance to the kind Locke actually uses. ${ }^{29}$ To make a methodological suggestion: While there is good sense in holding that accounts of what an author meant should connect up tightly with the way his contemporaries could understand him, we want to be able to say that his contemporaries-even readers as discerning as Hume-misunderstood him. Locke's foray into history may or may not have played an important role in scotching the snake of patriarchalism, but in any case the snake is dead. So we can leave Locke's historical contract behind, where Locke left Filmer and his "glib Nonsence." ${ }^{30}$ I turn, then, first to Locke's theory of obligation, second to his theory of legitimacy.

Locke poses himself the problem of how we become obliged to the state when he writes, "Every Man being, as has been shewed, naturally free, and nothing being able to put him into subjection to any Earthly Power, but only his own Consent; it is to be con-

${ }^{27}$ Though not, significantly, in his reading of English legal history. See J. G. A. Pocock, The Ancient Constitution and the Feudal Law (New York: Norton, 1967), especially pp. 187-190, 235-238.

${ }^{28}$ David Hume, "Of the Original Contract," in his Essays: Moral, Political, Literary (Great Britain: Oxford University Press, 1974), pp. 460, 473, 456.

${ }^{29}$ Josiah Tucker, $A$ Treatise concerning Civil Government (New York: Augustus M. Kelley, 1967), pp. 156, 122-146. The brackets and italics are Tucker's.

${ }^{30}$ Treatises, preface, p. 155. 
sidered, what shall be Understood to be a sufficient Declaration of a Mans Consent, to make him subject to the laws of any Government." "' I say "how we become obliged," not "how it is we are obliged," because Locke holds that children are in no way obliged to obey the law: "A Child is born a Subject of no Country or Government. He is under his Fathers Tuition and Authority till he comes to Age of Discretion; and then he is a Free-man, at liberty to decide what Government he will put himself under; what Body Politick he will unite himself to." ${ }^{32}$ We need not worry about screaming little banshees, who in Locke's view love authority, ${ }^{33}$ being free to wreak havoc; for, of course, they are obliged to obey their parents. Here Locke casts our natural freedom in a refreshingly straightforward way. It's not that people were once, in far-off days of folklore, somehow free; or even that the essence of a human being is to be free, whatever that might mean. It's that each and every one of us is born without political ties and enjoys an opportunity for genuine choice on outgrowing parental authority.

So Locke turns to consent to explain political obligation. A subject is obliged to obey the law, in his account, because he has consented. On reaching his majority, he elected, as Locke would say, to put himself under the laws of England. Consent here appears as an ongoing, inconspicuous process. Each person appends a metaphorical signature to the social contract, signing on a ghostly dotted line upon reaching his majority. That is why, holds Locke, many people imagine that political authority is natural: "The Consent of Free-men, born under Government, which only makes them Members of it, being given separately in their turns, as each comes to be of Age, and not in a multitude together; People

${ }^{31}$ Treatises II $\$$ I I 9 p. 365.

${ }^{32}$ Treatises II $\S_{\text {I I } 8}$ p. 365 ; also, for example, Treatises II $\S_{1} 5$ p. 296 , II $\S_{73}$ p. 333.

${ }^{33}$ This theme Locke orchestrates most impressively in his Education: "Children love Liberty. . . . They love something more, and this is Dominion" (p. 207); see too Education, pp. I 79, 229 . The theme connects up nicely with Locke's fear of the state's encroachment (Treatises I § Io p. I66, I § I06 p. 237, II §92 p. 345, II $\S_{143}$ p. 382) and his early perception of the politics of deception (see, for example, Tracts I I60, I66). 


\section{LOCKE'S DIVINE POLITICS}

take no notice of it, and thinking it not done at all, or not necessary, conclude they are naturally Subjects as they are Men." ${ }^{34}$

If Locke is to say that consent obliges, he needs at the very least an account of consent on which he can sensibly talk that way. Locke knows this, of course ("it is to be considered, what shall be understood to be a sufficient Declaration of a Mans Consent, to make bim subject to the Laws of any Government"), so he marches onstage the "common distinction of an express and a tacit consent, which will concern our present Case." 35 What will Locke take as tacit consent, and how far does it bind?

And to this I say, that every man, that hath any Possession, or Enjoyment, of any part of the Dominions of any Government, doth thereby give his tacit Consent, and is as far forth obliged to Obedience to the Laws of that Government, during such Enjoyment, as any one under it; whether this his Possession be of Land, to him and his Heirs for ever, or a Lodging only for a Week; or whether it be barely travelling freely on the Highway; and in Effect, it reaches as far as the very being of any one within the Territories of that Government. ${ }^{36}$

If so uninteresting an act as residence suffices to generate the obligation to obey the law, with what iron clamps does express consent shackle us?

Whereas he, that has once, by actual Agreement, and any express Declaration, given his Consent to be of any Commonweal, is perpetually and indispensably obliged to be and remain unalterably a Subject to it, and can never be again in the liberty of the State of

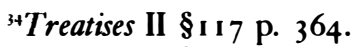

${ }^{35}$ Treatises II § I I9 p. 365 .

${ }^{36}$ Treatises II $\S_{1}$ I 9 p. 366. C. B. Macpherson, "The Social Bearing of Locke's Political Theory,"Western Political Quarterly 7 (March 1954): 18, reprinted in Schochet, Life, Liberty, and Property, p. 8o, reads the "being" in the last clause as a noun, the person's essence, thereby suggesting a curious existential twist. In Possessive Individualism, p. 250 , Macpherson lends it a rather sinister role in his class analysis. I take that "being" to be a verb, paralleling "travelling," and so take Locke to say that merely being inside the boundaries counts as tacit consent. 
Nature; unless by any Calamity, the Government, he was under, comes to be dissolved; or else by some publick Act cuts him off from being any longer a Member of it. ${ }^{37}$

Each individual, then, is obliged to obey the law because he has consented; but consent may be as minimal as residence.

Legitimacy, though, is another matter. It is generated by the hypothetical choice of rational agents. Illustrative here is Locke's argument for majority rule. He starts by asserting flatly that it and unanimity are the only feasible choice procedures. "For if the consent of the majority shall not in reason, be received as the act of the whole, and conclude every individual; nothing but the consent of every individual can make any thing to be the act of the whole," he declares, pointing out that nothing would ever be approved in any public assembly on the unanimity principle. ${ }^{38}$ The rather arbitrary exclusion of other alternatives need not detain us here. Note how Locke goes on to reject unanimity: "Such a Constitution as this would make the mighty Leviathan of a shorter duration, than the feeblest Creatures; and not let it outlast the day it was born in: which cannot be suppos'd, till we can think that Rational Creatures should desire and constitute Societies only to be dissolved. For where the majority cannot conclude the rest, there they cannot act as one Body, and consequently will be immediately dissolved again." 39 We can infer from the contract that people wish to have a government; presumably they wish it to do something; so if people are rational agents, if we can make painfully obvious inferences from their behavior to their ends, we can rule out certain proposals as not meeting those ends.

Locke employs similarly structured arguments again and again. Indeed, he does so extensively enough for us to say that he wields the contract also as a purely hypothetical argument. Regardless of the history of the matter, and regardless of our own consent, tacit or express, we can make observations about the proper behavior of government simply by inferring people's ends

${ }^{37}$ Treatises II $\S_{1} 2$ I p. 367.

${ }^{38}$ Treatises II $\$ 98$ p. 350 .

${ }^{39}$ Treatises II $\$ 98$ p. $35 \mathrm{I}$. 
in forming it. Consider: the "power of the Society, or Legislative . . . can never be suppos'd to extend farther than the common good," since people leave the state of nature "only with an intention in every one the better to preserve himself his Liberty and Property; (For no rational Creature can be supposed to change his condition with an intention to be worse)"; prerogative cannot be "an Arbitrary Power to do things hurtful to the People," since "a Rational Creature cannot be supposed when free, to put himself into Subjection to another, for his own harm"; the legislature must follow the familiar path of free elections and independent action, since "the People having reserved to themselves the Choice of their Representatives, as the Fence to their Properties, could do it for no other end, but that they might always be freely chosen, and so chosen, freely act and advise, as the necessity of the Commonwealth, and the publick Good should, upon examination, and mature debate, be judged to require"; and finally, there must be a rule of law, since "Absolute Arbitrary Power, or Governing without settled standing Laws, can neither of them consist with the ends of Society and Government, which Men would not quit the freedom of the state of Nature for, and tie themselves up under, were it not to preserve their Lives, Liberties and Fortunes; and by stated Rules of Right and Property to secure their Peace and Quiet." +0

Thinking along these lines, Locke outlines what we would think of as a theory of legitimacy, laying down the boundaries of state action beyond which revolution is justifiable: "since it can never be supposed to be the Will of the Society, that the Legislative should have a Power to destroy that, which every one designs to secure, by entering into Society, and for which the People submitted themselves to the Legislators of their own making; whenever the Legislators endeavour to take away, and destroy the Property of the People, or to reduce them to Slavery under Arbitrary Power, they put themselves into a state of War with the People, who are thereupon absolved from any farther Obedience, and are left to the common Refuge, which God hath pro-

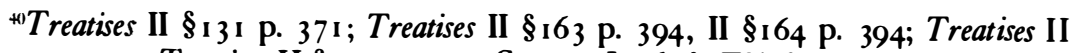
$\$ 222$ p. 43 I; Treatises II $\$ 137$ p. 377 . See too Locke's Third Letter for Toleration, in Works VI: 212. 
vided for all Men, against Force and Violence." +1 Since rational agents would not approve certain behavior, that behavior can be ground for revolution, only thinly disguised in Locke's talk of our divinely allotted common refuge. ${ }^{+2}$ Not every illicit act either should or will be responded to so violently: "he that appeals to Heaven, must be sure he has Right on his side, and a Right too that is worth the Trouble and Cost of the Appeal"; and, of course, "Great Mistakes in the ruling part, many wrong and inconvenient Laws, and all the slips of humane frailty will be born by the People, without mutiny or murmur," for "People are not so easily got out of their old Forms, as some are apt to suggest."

Our consent, then, produces an obligation to obey the law; our ends yield a measuring rod of legitimacy by which we can assess our government. These claims are plausible. But Locke needs a good deal more to fill out this political theory, or so I want to argue.

Let me begin with the theory of obligation. Talk of consent immediately invites cynical sneers, especially from readers aware of the machinations of the modern totalitarian state: suitably stretched and redescribed with loving philosophical care, anything we do can count as consent. Yet for all the slipperiness of consent, an important restriction is built into its very logic. One can take as consent only those acts that allow an alternative, a way of refusing consent. Therefore, if our very being within the territories of the government is to count as consent, we must be allowed to leave. Those governments, then, that deny or im-

${ }^{41}$ Treatises II $\$ 222$ p. 430 . Locke sometimes says the judge is God, sometimes

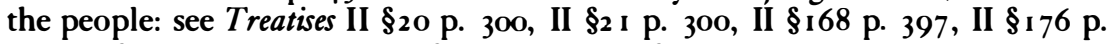
404 , II $\$ 240$ pp. $444-445$, II $\$ 24$ I p. 445 , II $\$ 242$ p. 445 ; Letter, p. I 29. Note Locke's passing comment in defending this right of revolution: "Are the People to be blamed, if they have the sence of rational Creatures, and can think of things no otherwise than as they find and feel them?” (Treatises II $\$ 230$ p. 436).

${ }^{42}$ Locke indulges here in what I can see only as a touch of mystification: "Rebellion," he says, is "an Opposition, not to Persons, but Authority, which is founded only in the Constitutions and Laws of the Government" (Treatises II $\$ 226$ p. 433). Yet, as Locke himself noted in a manuscript, "Allegiance is neither due nor paid to right or Government which are abstract notions but only to persons having right or government," in John Dunn, The Political Thought of Jobn Locke (Cambridge: Cambridge University Press, 1969), p. I48n.

${ }^{43}$ Treatises II I $_{7} 6$ p. 404; Treatises II $\$ 225$ p. 433 , II $\$ 223$ p. 432 . 


\section{LOCKE'S DIVINE POLITICS}

pede emigration forfeit the claim to authority from tacit consent: "No Government can have a right to obedience from a people who have not freely consented to it." Usurpers and conquerors, Locke tells us, gain no right to rule until the submission of the subjects can plausibly be called free.

Locke must dwell on tacit consent, since express consent is rare; so I will focus my attention on tacit consent here. Schematically speaking, Locke wants to move from some behavior in the world to consent, then (for both express and tacit consent) from consent to obligation. Accordingly, he needs some theory of interpretation on which the behaviors he nominates can plausibly be understood as consent, and he needs some moral theory on which consent generates obligation. The moral theory must also fix terms by showing what sort of consent generates what sort of obligation.

I mean to put off consideration of the moral theory to the next section of the chapter, but it seems worth noting here an elementary confusion in Locke's attempt to fix terms. We need to distinguish between the manner in which consent is given, express or tacit, and the extent of approval that the consent demonstrates, from hearty to grudging. It is sensible to think that hearty approval should generate a more enduring or demanding obligation than should grudging toleration, but Locke appeals instead to express consent. Perhaps he takes it for granted that when we expressly consent, we heartily approve; and when we tacitly consent, we less heartily or only grudgingly approve. That isn't necessarily the case, however. Putative communists signing a vow that they will faithfully uphold the Constitution consent expressly but are only grudgingly tolerant. Staunch conservatives continuing the family structure consent tacitly but are overwhelmingly enthusiastic. Express consent may generally be a good sign of hearty approval, but it is curious that Locke focuses on the manner of consent instead of the extent of the underlying approval.

There are imposing obstacles too in the way of a theory of

${ }^{4}$ Treatises II $\$$ I 92 p. 412. Compare Theodore Waldman, "A Note on John Locke's Concept of Consent," Etbics 68 (October 1957): 47. 
interpretation. Hume suggests two pointed criticisms. ${ }^{45}$ Some people, he notes, are too poor to emigrate. The alternative required for consent must be more than a logical possibility if consent is to be more than an academic chimera, but the freedom of the poor to leave is purely formal. Hume notes too that since people do not understand that obligation depends on consent, it is "absurd to infer a consent or choice"; should we take consent to contain any element of intentionality or volition, the point is well taken. Locke might wish to say that still we can take certain behavior to signify that the actor would consent. But such a subjunctive consent doctrine would be far removed from Locke's official position, and would itself face serious problems.

A theory of interpretation would also have to show what we consent to. Locke, of course, wishes to say that we consent to the government's rule, but here we can deploy against him his own distinction between state and society. Moving from one state to another is not the casual or even momentous step of some autonomous agent, some desiccated, anomic cell. It means wrenching deep ties with family and friends, perhaps culture and language. If residence indicates consent at all, that consent is to any and all of a set of items bundled together, comprising state and society. One person might consent (though speaking of consent here at all seems contrived) to the country's language, but oppose economic institutions and the state. Another might unpack the bundle we call the state, and consent to the judicial system but oppose a tiresome bureaucracy. It will require investigation in each case to determine to just what (if anything) each individual is consenting. It would be an extraordinary coincidence if all were consenting to the state. Since emigration means leaving state and society behind, it functions badly as an alternative showing that residence means consent to the state. ${ }^{46}$

Complications of a different sort arise when we ask whether

${ }^{45}$ Hume, "Of the Original Contract," in Essays, pp. 46I-462.

${ }^{46}$ Those interested in pursuing consent theory to either its logical fulfillment or its reductio ad absurdum might consult Herbert Spencer, "The Right to Ignore the State," in his Social Statics (New York: Schalkenbach, 1970), pp. I 85- I 94. Spencer removed the chapter from later editions of the book. Similarly, see Lysander Spooner, No Treason (Colorado Springs: Ralph Myles, I973). 
this reading is a reconstruction of Locke. For surely three separate contract arguments do not jump out of the pages of the Treatises. The text is more evasive. In particular, Locke's deployment of the contract in two different affirmative ways raises a host of questions. We want a theory illuminating the relationships between obligation and legitimacy. True, Locke says that "no Government can have a right to obedience from a people who have not freely consented to it." But that proviso is awfully vague. It will not bear the weight that any concrete line of interpretation will place on it. When is consent free?

Since legitimacy and obligation are generated by independent mechanisms, by (respectively) the hypothetical behavior of rational creatures and the consent of actual ones, there is a possibility they will diverge. A government might be legitimate, but its citizens might not have an obligation to obey the law. We cannot, however, find the converse case, in which citizens are obliged to obey an illegitimate government. For Locke, again, is clear that when the legislature "put themselves in a state of War with the People, [the people] are thereupon absolved from any farther obedience." So legitimacy and obligation are not wholly independent for Locke. One tempting proposal is this: the less completely legitimate the government, the less we are obliged to obey it, for the less free our consent is. But that will depend on just how the government is forfeiting its legitimacy. It may do so in ways that don't even begin to make consent look forced; the crucial alternatives to consent, options such as emigration, may remain completely open. Similarly, it will depend on whether Locke structures consent as a binary concept - one either consents or doesn't - or as a continuum, allowing degrees of consent. There are fascinating complications here that I will not pursue. My point is simply that Locke leaves all questions on these matters unanswered and even unasked.

Faced with such difficulties, scholars have suggested two other ways of interpreting Locke's argument for obligation. Hanna Pitkin has suggested that we forget consent and allow rational choice to do all the work: "For now the Lockean doctrine becomes this: your personal consent is essentially irrelevant to your obligation to obey, or its absence. Your obligation to obey 
depends on the character of the government - whether it is acting within the bounds of the (only possible) contract." ${ }^{+7}$ Locke, though, holds that "only his own Consent" can put a man "into subjection to any Earthly Power," so Pitkin's reading commits us to holding that Locke flatly misunderstood his own view. Worse, it's not clear that consent and rational choice obligate the same people. On the consent reading, it remains an open question whether we can be obliged to illiberal but not hopelessly absolutist states, because Locke is not clear about when residence really is consent. ${ }^{48}$ Finally, in Locke's account, children are not obliged to obey the law - quite plausibly on the consent reading, but only unacceptably ad hoc provisos will make the point precipitate out of Pitkin's solution.

A. John Simmons acknowledges that "we can believe Locke when he asserts that he holds personal consent to be the sole ground of political obligation," but he goes on to find that "Locke's primary error, then, seems to lie in his confusion of consent with other grounds which may be sufficient to generate obligations." ${ }^{49}$ Simmons argues that those other grounds are the enjoyment of benefits, which may oblige by the principle of fairness, or considerations of gratitude. Locke invites such a reading, not as revision but as textual exegesis: "Since the Government has a direct Jurisdiction only over the Land, and reaches the Possessor of it . . . only as he dwells upon, and enjoys that:

+7Pitkin, "Obligation and Consent," p. 996 and generally pp. 994-996, in Philosophy, Politics and Society, ed. Laslett, Runciman, and Skinner, $4^{\text {th }}$ ser., p. 57 and generally pp. 53-57.

${ }^{+8}$ The early Locke is especially stubborn in clinging to the view that noxious laws (not states) oblige to passive obedience; see, for example, Tracts I p. I 52 ; Tracts II pp. 220, 237; Letter, pp. I 27, I 29. Perhaps if there's room for a n obligation to bad laws, we can drum up an obligation to not-so-good states by playing a bit fast and loose with the fallacy of composition; but Locke is rather nastier about passive obedience in Treatises II $\$ 228$ pp. $434-435$.

${ }^{+9}$ A. John Simmons, "Tacit Consent and Political Obligation," Pbilosophy \& Public Affairs 5 (Spring 1976): 286, 288. See too Waldman, "Note on John Locke's Concept of Consent," p. 48; John Dunn, "Consent in the Political Theory of John Locke," Historical Journal Io (1967): I62, reprinted in Schochet, Life, Liberty, and Property, p. I 39. Simmons has pursued these issues further in "The Principle of Fair Play," Pbilosopby \& Public Affairs 8 (Summer 1979): 307-337, and in Moral Principles and Political Obligations (Princeton, N.J.: Princeton University Press, 1979), which incorporates both articles. 
The Obligation any one is under, by Virtue of such Enjoyment, to submit to the Government, begins and ends with the Enjoyment." ${ }^{50}$ Is Locke appealing to the enjoyment itself ? Or is consent still the key, enjoyment being merely the sign of consent? Recommending that we take Simmons's view as our explication of Locke is the Procrustean lengths to which we must stretch the concept of consent to make residence fit; militating against it is Locke's repeated claim that his is a consent doctrine. Unfortunately, Simmons's approach seems to yield practical results equivalent to Locke's, or to fall within the same foggy cloud of indeterminacy. For we cannot imagine a case where residence doesn't entail some enjoyments (say, national defense) and feel any assurance as to Locke's views.

Nonetheless, the best bet seems to be that we stick to the consent reading, since political obligation is not the only subject on which Locke employs an attenuated sense of consent. Money "has its value only from the consent of Men," and Locke takes its use in turn as a consensual justification of economic inequality: "Men have agreed to disproportionate and unequal Possession of the Earth, they having by a tacit and voluntary consent found out a way, how a man may fairly possess more land than he himself can use the product of, by receiving in exchange for the overplus, Gold and Silver." ${ }_{1}$ Flexing heroically liberal muscle, Locke declares, "The Supream Power cannot take from any Man any part of his Property without his own consent"; but then he concedes, “'Tis true, Governments cannot be supported without great Charge, and 'tis fit every one who enjoys his share of the Protection, should pay out of his Estate his proportion for the maintenance of it. But still it must be with his own Consent, i.e. the Consent of the Majority, giving it either by themselves, or their Representatives chosen by them." ${ }^{2}$ Most strikingly, in denying that "Property in Land . . . gave any Authority over the

${ }^{50}$ Treatises II $\S_{12} 1$ p. 367 . I've rearranged Locke's italics.

"Treatises II \$50 pp. 319, 320; see too John Locke, Some Considerations of the Consequences of lowering the Interest and raising the Value of Money, in Works V:22; John Locke, Further Considerations concerning raising the value of money, in Works $\mathrm{V}: 139$.

${ }^{2}$ Treatises II $\S_{1} 3^{8}$ p. 378 , II $\S_{140}$ p. 380. 
Persons of Men," Locke states that "the Authority of the Rich Proprietor, and the Subjection of the Needy Beggar began not from the Possession of the Lord, but the Consent of the poor Man, who preferr'd being his Subject to starving. " ${ }_{53}$ A decidedly odd conception of consent animates these claims. If one consents to money and inequality, if one consents when a majority votes, if one consents when the alternative is starving, one may perhaps be pardoned for not cherishing one's right to consent.

Locke has an internally coherent argument for our obligation to obey the law, but the argument is seriously incomplete as it stands so far. He needs an account of why consent is attenuated as residence in the lands of a tolerably liberal state obliges. Indeed, he needs a general account of why consent obliges at all. That account presumably would turn in the Treatises on the law of nature, but, again, Locke thinks "it would be besides my present purpose, to enter here into the particulars of the Law of $\mathrm{Na}$ ture, or its measures of punishment," or, for that matter, the status of that law. So we must turn elsewhere. Similarly, Locke has an internally coherent argument for our right to revolt against a patently illiberal state, but that argument too is seriously incomplete as it stands so far. Assuming we are convinced by Locke's arguments that a liberal state serves the protection of property better than an anarchist society would, we still need an account of why it should be thought that we all take as our end the protection of property. That account presumably would turn on some general theory of human motivation and rationality, and might well connect up neatly with a moral theory showing what our ends ought to be. But Locke does not even begin the relevant arguments in the Treatises. (He had good tactical reasons for refraining. As we will see, his views on the law of nature were far more unorthodox than anyone could have gleaned from the Treatises' vague waves in its direction. His silence thus allows the contemporary reader a placid nod of the head.) So again we must turn elsewhere. Accordingly, I will now attempt a reconstruction of Locke's views on morality, motivation, and rationality.

${ }^{53}$ Treatises I $\$ 43$ pp. I 88- I 89. 
Pleasure, Rationality, and Morality ${ }^{54}$

Even the most cursory reading of Locke's Essay concerning $\mathrm{Hu}$ man Understanding reveals an author determined to launch a bold attack on received views in epistemology and substitute a thoroughgoing empiricism. We need only glance down the title pages of Book I of the Essay to get the point: "No innate Speculative Principles" proclaims one chapter; "No innate Practical Principles" chimes the next, in emphatic chorus. The mind, Locke holds, starts off entirely empty. The imagery, if not the argument, has become the common stock of intellectual company. "The senses at first let in particular Ideas, and furnish the yet empty Cabinet"; "white Paper receives any Characters," "white Paper, void of all Characters, without any Ideas." Sense experience and introspection are the sole sources of ideas; since introspection requires something to introspect upon, sense experience is the fundamental source. Discussing "external and internal Sensation," as he calls them, Locke notes: "These alone, as far as I can discover, are the Windows by which light is let into this dark Room. For, methinks, the Understanding is not much unlike a Closet wholly shut from light, With only some little openings left, to let in external visible resemblances, or Ideas of things without." "ss Yet amidst all the thunderous fanfare and clamoring cavalcade, Locke declares: "Nature, I confess, has put into Man a desire for Happiness, and an aversion to Misery: These indeed

${ }^{54}$ The best works I have found in this area are Hans Aarsleff, "The State of Nature and the Nature of Man in Locke," in Jobn Locke: Problems and Perspectives, ed. John W. Yolton (Cambridge: Cambridge University Press, I 969); and Patrick Riley, Will and Political Legitimacy (Cambridge, Mass.: Harvard University Press, 1982), chap. 3.

${ }^{55}$ Essay, pp. 55, 81, I04, 162-163. See too the "Defence of Mr. Locke's Opinion concerning Personal Identity," in Works II: I94n. ("If the mind was once a mere rasa tabula, it will soon appear not only from whence it receives all its furniture"); "Of the Conduct of the Understanding," in Works III:272 ("We are born ignorant of every thing"); Law, p. 145 ("No principles, either practical or speculative, are written in the minds of men by nature"); Education, pp. 1 I 5 ("I imagine the Minds of Children as easily turned this or that way, as Water it self"), 275 ("'Tis as impossible to draw fair and regular Characters on a trembling Mind as on a shaking Paper"), 325 ("a Gentleman's Son, who being then very little, I considered only as white Paper, or Wax, to be moulded and fashioned as one pleases"). 
are innate practical Principles, which (as practical Principles ought) do continue constantly to operate and influence all our Actions, without ceasing: These may be observ'd in all Persons and all Ages, steady and universal." ${ }_{56}$ As Locke goes on to argue, the point poses only terminological difficulties for his epistemology. Psychological inclinations are different from knowledge of moral truth. Locke wishes to deny the innateness only of the latter. Still, innate practical principles are the anchor of his moral theory, and I wish to develop his conception.

Suppose we can arrange a monotonically varying spectrum of mental states, from intensely agreeable to intensely disagreeable, and mark off a zero point. Locke proposes to call the positive states pleasure, the negative ones pain: "For whether we call it Satisfaction, Delight, Pleasure, Happiness, etc. on the one side; or Uneasiness, Trouble, Pain, Torment, Anguish, Misery, etc. on the other, they are still but different degrees of the same thing." We should not take pleasure, then, as signifying only hedonistic consciousness, orgiastic ecstasy, and the like. Locke wants to discuss agreeable mental states of whatever sort, and he cares little how we label such states. (Should we, then, take his mention of "the happiness that all Men so steadily pursue, consisting in pleasure" 188 as a linguistic reminder or a slip?) Of fhand dismissals of crude libidinal satisfactions will not do when Locke tells us that "things then are Good or Evil, only in reference to Pleasure or Pain. That we call Good, which is apt to cause or increase pleasure or diminish Pain in us; or else to procure, or preserve us the possession of any other Good, or absence of any Evil. And on the contrary we name that Evil, which is apt to produce or increase any Pain, or diminish any Pleasure in us; or else to procure us any Evil, or deprive us of any Good." Locke makes explicit in his Thoughts concerning

${ }^{56}$ Essay, p. 67. In Treatises I $§ 86$ pp. 222-223, the desire for self-preservation appears as "a Principle of Actions" God endows us with. In Education, p. I 59, "God has stampt certain Characters," or "Original Tempers," "upon Men's Minds." But that is perfectly consistent with Essay, p. 6r9, where God "has stamped no original Characters on our Minds," for in the latter discussion the Characters in question are again bits of knowledge.

${ }^{57}$ Essay, pp. I 28- 1 29; also Essay, p. 232.

${ }^{58}$ Education, p. 249.

${ }^{50} E s s a y$, p. 229 . Locke readily grants the subjectivism suggested here in Essay, p. 268: "The various and contrary choices, that Men make in the World, 
Education what he suggests in the Essay: "Good and Evil, Reward and Punishment, are the only Motives to a rational Creature." It's not that men of ten happen to be concerned with pleasure and pain. It's rather that this concern and the accompanying calculus comprise the defining core of rationality. (Accumulation of pleasure, not property, is for Locke "the essence of rational conduct."61)

Despite Locke's tireless refrain that "all we desire is only to be Happy,"62 his official position in the Essay is spelled out differently. ${ }^{63}$ Locke knows that we don't always pursue apparent goods, and he appeals to uneasiness as the great propellant of human action. We always respond to pains nagging away at us, but more than a recognition of the pleasure-causing properties of something is required for us to strive for it. Required is desire, itself "a state of uneasiness." ${ }^{4}$ Locke summarizes the practical implications of his view in his memorable cameo of the drunkard driven by the uneasiness of missing "the tickling of his palate with a glass of Wine, or the idle chat of a soaking club" back "to the Tavern, though he has in view the loss of health and plenty, and perhaps of the joy of another life." ${ }^{\circ 5}$ Locke's account of human motivation connects up neatly with his elegant if untenable

do not argue, that they do not all pursue Good; but that the same thing is not good to every Man alike."

${ }^{60}$ Education, p. 152.

${ }^{6}$ Macpherson, "Social Bearing," p. I2, reprinted in Schochet, Life, Liberty, and Property, p. 77. Also Macpherson, Possessive Individualism, pp. 221 , $232-238$. It would be easy enough to pile up quotations refuting Macpherson's reading on this point. My favorite: "Covetousness, and the Desire of having in our Possession, and under our Dominion, more than we have need of, being the Root of all Evil, should be early and carefully weeded out, and the contrary Quality of a Readiness to impart to others, implanted" (Education, pp. $213-$ 214). Macpherson slips around such passages in Possessive Individualism, pp. 236-237. Leo Strauss, Natural Right and History (Chicago: University of Chicago Press, 1953), p. 246, also takes Locke as wanting "to prove that the unlimited acquisition of wealth is not unjust or morally wrong."

${ }^{62}$ Essay, p. 283; also Essay, pp. 274-275, 279, 345, 346; Education, p. 222; Reasonableness, in Works VII:I49; John Locke, "Of Ethics in General," in Lord King, The Life of Jobn Locke (London, 1829), p. 306; King, Life of Jobn Locke, p. II5.

${ }^{63}$ The relevant discussion is in Essay, pp. 233-285, especially pp. 250255.

${ }^{64}$ Essay, p. $25 \mathrm{I}$.

${ }^{65}$ Essay, p. 253. 
doctrine of suspension of the will, ${ }^{66}$ and much could be made of the import of the whole for understanding those restless souls of liberal society. With due regret, I bring up all these matters only to drop them at once, for they make no difference to Locke's moral theory. Locke bemoans the quirks of human judgment that leave future goods discounted and clearly thinks we ought to respond to pleasure and pain alike. ${ }^{67}$ So we cannot object later by saying, "Ah, but that great good doesn't entice us," for Locke can respond simply, "But it should." To avoide needless complications, I simply grant Locke that we ought exclusively to pursue pleasure and avoid pain.

On to morality, "the proper Science and Business of Mankind in general." ${ }^{8}$ Locke holds that "Morally Good and Evil . . . is only the Conformity or Disagreement of our voluntary Actions to some Law, whereby Good or Evil is drawn on us, from the Will and Power of the Law-maker; which Good and Evil, Pleasure or Pain, attending our observance, or breach of the Law, by the Decree of the Law-maker, is that we call Reward and Punishment." ${ }^{69}$ Men judge their actions sometimes by civil statutes, sometimes by the received views of their society; these "laws" are vital in maintaining the social and political world. The "only true touchstone of moral Rectitude," however, is the divine law, or God's commands. ${ }^{70}$ The last foundational premise comes in Locke's version of the doctrine that moral considerations are overriding: "The Rewards and Punishments of another Life,

${ }^{6}$ Locke provides no account of why we suspend the will when we do, or why, having done so, we make the decisions we do. In the absence of any such account, both processes are just as plausible subjects for the reign of causal determinism as the initial will buffeted by pleasures and pains.

${ }^{67}$ See the discussion of "wrong judgments" in Essay, pp. 272-281, and John Locke, "Thus I Think," in King, Life of Jobn Locke, p. 304: "It is a man's proper business to seek happiness and avoid misery" (my italics). Locke casts suspension of the will in splendidly Platonic terms in Education, pp. 138, 143, $147-148,151$, but the point seems much the same.

${ }^{68}$ Essay, p. 646; compare Essay, pp. 46, 87, 1 31, 302, 350-35 I; Education, p. 232; John Locke, "Of Study," in Axtell, Educational Writings, pp. 41 I , 415 ; Locke, "Of the Conduct of the Understanding," in Works III:244-245.

${ }^{60}$ Essay, p. 35 I. See too Essay, pp. 69, 74; Reasonableness, in Works VII: 14; Education, p. 24I; Tracts I p. 124; Tracts II p. 22 I; Locke in Dunn, Political Thougbt, p. I.

${ }^{70}$ Essay, p. 352. 
which the Almighty has established, as the Enforcements of his Law, are of weight enough to determine the choice, against whatever Pleasure or Pain this Life can shew, when the eternal State is considered but in its bare possibility, which no Body can make any doubt of." We need not let Locke long rehearse his fire-and-brimstone strictures on the "unspeakable rewards and punishments in another world" to begin to sense the project for justifying morality. ${ }^{72}$ It is an ambitious project indeed: Locke wants to reconcile self-interest and morality by showing that acting morally is in one's self-interest. By following the rules; his idea is, one goes to heaven and basks in unutterable delight; by breaking them, one goes to hell and flounders in enormities of pain. To carry through the argument, Locke needs to show the existence of God, and how we know what God commands.

First, then, the argument for God. Locke is surpassingly fond of the argument from design. He tells us that "the visible world is constructed with wonderful art and regularity," that "Nature never makes excellent things, for mean or no uses," that "the Wisdom and Goodness of the Maker plainly appears in all the Parts of this Stupendious Fabrick, and all the several degrees and ranks of Creatures in it." "13 God becomes "the Architect," and "after contemplating the beauty of the objects to be observed, their order, array, and motion," we ask "what was the cause, and who the maker, of such an excellent work" and decide that "there must be a powerful and wise creator of all these things." "74 Are you unimpressed by the stunning regularity of the world? Do you look about and see not beauty and order but waste and carnage in nature and politics? Recall that you are a frail being of limited intellectual capacity; in "this our dark and short-sighted state," we cannot hope to fathom the depths of God's wisdom manifest in the world. ${ }^{75}$ Humility is called for, since "it will better become the temper of a Christian patiently to obey than to

"Essay, p. 28I.

"Reasonableness, in Works VII: 122.

${ }^{13} L a w$, p. 15 ; Essay, pp. I 1 $3,148$.

${ }^{74}$ Essay, p. 447; Law, p. 1 53 . See too Essay, pp. 89, 560; Treatises I §53 p. 197; Locke, "Of The Conduct of the Understanding," in Works III:245; Reasonableness, in Works VII:I 35.

${ }^{75}$ King, Life of Jobn Locke, p. 3 I 5. 
presumptuously complain and murmur that God hath not put human affairs into a posture suited to his humour or squared the economy of the world or frame of the Temple according to the model of his brain." "' Locke's theory itself accounts for our objections to it. That makes it unfalsifiable, but its unfalsifiability is not the result of a series of ad hoc moves designed to save the initial theory. Instead, it is a direct outcome of the initial theory itself. God has created a world ordered in such a complex way that we cannot recognize the order in it. Maybe; maybe not. Theories structured this way can be false. But the concession that we might not recognize the order in God's creation does not strengthen the argument from design; it destroys it. The world's apparent lack of order can hardly serve as a reason for believing in God.

It is not, however, the argument from design that Locke has in mind when he announces, "I have proved there is a God." "7 The proof is the one in the Essay, which Locke runs through twice. ${ }^{78}$ Here I combine his two presentations:

I. Something cannot emerge out of nothing. ("Non-entity cannot produce any real being.")

2. The cause is superior to the effect. ("That what had its Being and Beginning from another, must also have all that which is in, and belongs to its Being from another too.")

Therefore:

3. The first cause is the most powerful being. ("Whatsoever is first of all things, must necessarily contain in it, and actually have, at least, all the Perfections that can ever after exist.")

${ }^{76}$ Tracts I p. I36; see too Education, p. 305; Reasonableness, in Works VII: 34. Compare John Smith, "The Excellency and Nobleness of True Religion," in The Cambridge Platonists, ed. C. A. Patrides (Cambridge, Mass.: Harvard University Press, 1970), p. 190.

${ }^{77}$ Works IV:289; see too Works IV:276, 293; Essay, pp. ıoo, 558, 621.

${ }^{78}$ Essay, bk. IV, chap. X, pp. 6r9-630. All quotations in the next two paragraphs are from this chapter. Since Locke can conceive of thinking material substances, I have avoided importing any suggestion of dualism. Note here $\mathbf{M}$. R. Ayers, "Mechanism, Superaddition, and the Proof of God's Existence in Locke's Essay," Philosophical Review 9o (April I 98I): 208-25 I. 
Now:

4. I know I exist. ("Man has a clear Perception of his own Being.")

5. I am a knowing and intelligent being.

Therefore, by (3):

6. That first cause is the supremely knowing, intelligent being.

Concludes Locke: "Our Reason leads us to the Knowledge of this certain and evident Truth, That there is an eternal, most powerful, and most knowing Being; which whether any one will please to call God, it matters not. The thing is evident, and from this Idea duly considered, will easily be deduced all those other Attributes, which we ought to ascribe to this eternal Being."

This proof is a wild tangle of odd premises and faulty inferences. It's not at all clear why (I), which we might call the nofree-lunch principle of metaphysics, or (2), which we might call the all-downhill-from-here principle, should be true. We can conceive of things popping into thin air, and we can conceive, hypostatizing a bit, of evolution dredging human beings out of some primordial gunk. Locke says, unhelpfully, that (2) "is evident." A bit more provocatively, he tells us that we know (I) "by an intuitive certainty," which he likens to a sadly unclear proposition about right angles. ${ }^{79}$ But a good deal more argument will be required to ground either premise successfully. Furthermore, I have saved Locke his silliest brummagem inference in restating the argument. Even granted (I) and (2), it does not follow that the first cause still exists. Locke accomplishes this move by a play on words, going from "Something must be from Eternity," a gloss on ( $\mathrm{I})$, to "If then there must be something eternal, let us see what sort of Being it must be." ${ }^{\text {"0 }}$ Finally, I wonder what

${ }^{79}$ Elsewhere and quite clearly: "'Tis as certain, that there is a God, as that the opposite Angles, made by the intersection of two straight lines, are equal. There was never any rational Creature, that set himself sincerely to examine the truth of these Propositions, that could fail to assent to them" (Essay, pp. 94-95).

${ }^{80}$ The point is in J. L. Mackie, Problems from Locke (Oxford: Clarendon, I 976), pp. 208-209; see too the treatment in J. L. Mackie, The Miracle of Theism (Oxford: Clarendon, r 982), p. I 20. The god of this argument rears his head momentarily in "Remarks upon Some of Mr. Norris's Books," in Works X:255. 
easy deductions will move Locke from his most powerful, knowing being of (6) to an omnipotent, omniscient being.

The existence of God is not all Locke thinks he can demonstrate. He often claims too that "moral Rules are capable of Demonstration: and therefore it is our own faults, if we come not to a certain Knowledge of them." ${ }^{81}$ Answering the importunate urgings of Molyneux that "the task must be undertaken," Locke apologizes: "I thought I saw that morality might be demonstratively made out; yet whether I am able so to make it out, is another question." ${ }_{82}$ Nonetheless, we can glean the outlines of the proposed demonstration, remarkably more direct than the project on divine command I am sketching in this section, from Locke's comments in the Essay. ${ }^{83}$ He says, for example, "I am bold to think, that Morality is capable of Demonstration, as well as Mathematicks: Since the precise real Essence of the Things moral Words stand for, may be perfectly known; and so the Congruity, or Incongruity of the Things themselves, be certainly discovered, in which consists perfect knowledge." ${ }^{84}$ Here Locke is tripped up in his own distinctions. I take it that Locke means real essence to denote the actual qualities of things in the external world, nominal essence the contents of our concepts. For modes, he says, the two essences coincide. ${ }^{85}$ Now the argument goes awry. Locke wields it to prove tautologies, as when he tells us that "Where there is no Property, there is no Injustice, is a Proposition as certain as any Demonstration in Euclid: For the Idea of Property, being a right to any thing, and the Idea to which the name Injustice is given, being the Invasion or Violation of that right; it

${ }^{81}$ Essay, p. 66. See too Essay, pp. 565, 643.

${ }^{82}$ Molyneux to Locke, in Works IX:291; Locke to Molyneux, 20 sep 1692, in Works IX:294. Tyrrell urged Locke to revise and publish his Essays on the Law of Nature (see Law, pp. 9, 1 o). See too Locke to Molyneux, 30 mar 1696, in Works IX:377; and Works IV: I 87 .

${ }^{83}$ I should note that in Essay, p. 549, and King, Life of Jobn Locke, p. I 20 , Locke is unmistakably claiming that the divine command account of morality is demonstrable (though in each passage he also unmistakably refers to the account I'm sketching here). I'll deal with that claim a bit later, in considering Strauss's (mis)construction of the argument.

${ }^{84}$ Essay, p. 5 I 6.

${ }^{85}$ See Essay, pp. 409-47 I, especially pp. 457-460; also, "Faith and Reason," shorthand journal entry from 27 aug 1676 , in Law, pp. 278-279. 
is evident" that the point is conceptually guaranteed ${ }^{86}$ But then it is evident too that it has no content, no bearing on our conduct, for if property means a right, we can always ask if land or liberty or anything else is properly called property. Perhaps Locke was misled by his erroneous claim that when we name a mode, real and nominal essence coincide, since our meaning starts and stops with our concept. Were that so, were the substances named in moral rules included only in unproblematic ways ${ }^{87}$ and were there such things as tautologies with substance, he could dream of his rigorous demonstration. But modes, the moral terms among them, can sensibly be used to refer to real essences divorced from nominal ones. By murder, we may mean to name a certain human activity, and it might require empirical investigation to understand its nature. The tautology problem aside, even moral propositions such as "murder ought to be punished" would be open to question. They could depend on not just a theory of punishment, but beliefs about the efficacy of punishment, the effects of a punishing institution such as the state or of the free employment of vigilantes, and so on. Some moral disagreements, though emphatically not all, rest firmly on factual disagreements. Locke would be the first to insist on the necessity of tackling the factual questions, not trying to evade them by verbal manipulations. ${ }^{88}$

Fortunately, though, the divine-command project is different from this purported demonstration, and the former does not fail

${ }^{86}$ Essay, p. 549. In his discussion of trifling propositions (Essay, pp. 609617 ), Locke tells us we may have certain knowledge of overtly definitional statements, "but 'tis a verbal Certainty, but not instructive"; rather surreptitiously he adds that we can have "instructive real Knowledge" of "Propositions, which af firm something of another, which is a necessary consequence of its precise complex Idea, but not contained in it" (Essay, p. 614). But what kind of necessity does Locke have in mind here? Would it be reading too much back into his text to see a glimmer of the synthetic a priori? I am inclined to say that the most instructive deductions only point out connections we hadn't noticed, but doubtless all deductive conclusions are contained in the premises. Are moral rules then supposed to be recondite deductive truths? and so illuminating, but empty? Or does Locke have in mind some kind of necessity other than deductive?

${ }^{87}$ Essay, pp. 516-517.

${ }^{88}$ See, for example, Essay, pp. 591-608, especially pp. 606-608. I am greatly indebted here to Mackie, Problems from Locke, pp. 90-93. 
as immediately and ignominiously as the latter. I propose to grant Locke the existence of God and continue to follow the project, so I turn to his account of our knowledge of God's will. Here we must first take note of a pronounced shift in Locke's views over the years. He begins by insisting that reason is capable of making out the law of nature. In the early Essays on the Law of Nature, we find labyrinthine formulations worthy of, say, Clarke or Cudworth: "What is proper now for the rational nature, in so far as it is rational, must needs be proper for ever, and the same reason will pronounce everywhere the same moral rules. Since therefore all men are by nature rational, and since there is a harmony between this law and the rational nature, and this harmony can be known by the light of nature, it follows that all those who are endowed with a rational nature, i.e. all men in the world, are morally bound by this law." ${ }^{89}$ In the Treatises, Locke even equates reason and the law of nature. ${ }^{* 1}$ And in the Essay, he warns, "I think they equally forsake the Truth, who running into the contrary extreams, either af firm an innate Law, or deny that there is a Law, knowable by the light of Nature, i.e. without the help of positive Revelation."

By The Reasonableness of Christianity Locke has changed his tune. There he fears "it is too hard a task for unassisted reason to establish morality in all its parts, upon its true foundation, with a

${ }^{89}$ Law, p. I 99; see too Law, p. I I I.

${ }^{90}$ Treatises II $\$ 6$ p. 289 . On a tenuously related problem: Locke writes in Treatises II $\S_{\text {I I }}$ p. 292 , "And Cain was so fully convinced, that every one had a Right to destroy such a Criminal, that after the Murther of his Brother, he cries out, Every one that findeth me, shall slay me; so plain was it writ in the Hearts of all Mankind." That writing looks suspiciously like an innate practical principle of the kind Locke is concerned to deny. The passage ought to be considered in light of Reasonableness, in Works VII: I 3, where, in explicating Romans ii. I 5 on "the law written in their hearts," Locke says easily, "By which . . . it is plain, that under the law of works, is comprehended also the law of nature, knowable by reason." Compare his treatment in "A Paraphrase and Notes on the Epistle of St. Paul to the Romans," in Works VIII:265-266. Locke also refers to "the light of nature" as "the transcript of the moral law in the Gospel" ("Error," in King, Life of Jobn Locke, p. 283). In these passages, Locke is wrestling with a problem familiar from medieval political theory: how reconcile one's beliefs with apparently opposed passages from Scripture?

${ }^{91}$ Essay, p. 75. 
clear and convincing light. ${ }^{{ }^{2} 2}$ Finally, in his controversy with Stillingfleet over the Essay, Locke seems flatly to deny the very possibility of human reason making out the principles on which the law of nature is based: "Though the light of nature gave some obscure glimmering, some uncertain hopes of a future state; yet human reason could attain to no clearness, no certainty about it. ${ }^{{ }^{9} 3}$ Leo Strauss understood this claim as the surrender of the entire project, and he accordingly offered a reading in which Locke has no genuine account of natural law. ${ }^{24}$ That reading rests on holding the late Locke to the early Locke's views, certainly an unsound approach for textual exegesis. We can, of course, search for some univocal teaching that a writer allegedly offers, and we can ruthlessly iron out all the discrepancies and contradictions we find. But political theorists, like the rest of us, can change their minds. Typically, their mature views do not spring from their heads fully formed, like Athena from Zeus's; instead theorists tenaciously struggle over problems, revising their views as they go. It must be an open question in any given case whether we can run together the early and late works. One of the weaknesses of the innocuous idea that a political theorist offers a teaching is that it blinds us to the typical pattern of development, even to the possibility of its holding in a given case. Worse, Strauss overlooked Locke's belief that reason and revelation are complementary, not antagonistic, modes of knowledge. Locke stakes out that position firmly in the Essay: "Reason is natural Revelation," and "Revelation is natural Reason enlarged by a new set of Discoveries communicated by GOD immediately,

${ }^{92}$ Reasonableness, in Works VII: I 39; also Reasonableness, in Works VII: I 40- I 47. But see Reasonableness, in Works VII: I 3, I 57 for explicit affirmations that reason can do the job. It's just that it hasn't, so Locke discards "the declarations of philosophers" as "a wild wood of uncertainty . . . an endless maze" (p. 143).

${ }^{93}$ Works IV:489; also Works IV:480; John Locke, A Tbird Letter for Toleration, in Works VI:493.

${ }^{94}$ Strauss, Natural Right and History, pp. 202-230, especially p. 220 ("We thus arrive at the conclusion that Locke cannot have recognized any law of nature in the proper sense of the term"). Strauss thought too that "Honour thy father and thy mother if they have deserved it of you" is a hypothetical imperative, but it is as categorical as "Honour thy father and thy mother" (p. 2 I9): neither hinges on the ends of the addressed agent. 
which Reason vouches the Truth of, by the Testimony and Proofs it gives, that they come from GOD." 95 The latter point is crucial, for it means to Locke that "Reason must be our last Judge and Guide in every Thing." 96

Reason judges and guides us to the word of God by identifying miracles. Locke defines a miracle as "a sensible operation, which, being above the comprehension of the spectator, and in his opinion contrary to the established course of nature, is taken by him to be divine." (Curiously, Locke chooses to build the indeterminacy problems of identifying miracles into his definition.) Now, enquires Locke, "what shall be a sufficient inducement to take any extraordinary operation to be a miracle?" When apparent miracles conflict, we may take the victorious force as the authentically divine one, "since God's power is paramount to all"- so "the producing of serpents, blood, and frogs, by the Egyptian sorcerers" is not a miracle. By extension, "uncontested revelation will stand too," for "it cannot be supposed God should suffer his prerogative to be so far usurped by any inferior being, as to permit any creature, depending on him, to set his seals, the marks of his divine authority, to a mission coming from him." Yet Locke is decidedly impatient with making out the argument: "The only revelations that come attested by miracles, being those of Moses and Christ, and they confirming each other; the business of miracles, as it stands really in matter of fact, has no manner of difficulty in it; and I think the most scrupulous or sceptical cannot from miracles raise the least doubt against the divine revelation of the Gospel." 97

The Testaments thus emerge as the word of God, stamped with divine assurance of their veracity. Having been certified by reason, they stand superior to those propositions normally within its jurisdiction. Says Locke, "The holy scripture is to me,

${ }^{95}$ Essay, p. 698.

${ }^{\circ}$ Essay, p. 704. See generally Education, p. 302; King, Life of Jobn Locke, p. I 2 ; John Locke, “A Discourse of Miracles," in Works IX:26 I-262.

${ }_{97}$ Locke, "A Discourse on Miracles," in Works IX:256, 259, 260, 261, 258. Locke manages to clear the ground by dismissing "what the Persees say of their Zoroaster, or the Indians of their Brama (not to mention all the Wild Stories of the religions farther East) [as] so obscure, or so manifestly fabulous, that no account can be made of it" (p. 258 ). 
and always will be, the constant guide of my assent; and I shall always hearken to it, as containing infallible truth, relating to things of the higher concernment. . . . I shall presently condemn and quit any opinion of mind, as soon as I am shown that it is contrary to any revelation in the holy scripture."98 (This position raises difficulties for Locke in his Letters on Toleration. Locke declares forthrightly again and again that believing your religion to be true is insufficient for enforcing it: "If that be sufficient to authorize you to use force, it will authorize any other magistrate of any other religion to use force also." 99 Yet in the Second Letter, he concedes, "When you can show any commission in Scripture, for the use of force to compel men to hear, any more than embrace, the doctrine of others that differ from them, we shall have reason to submit to it, and the magistrate have some ground to set up this new way of persecution." ${ }^{100}$ So a magistrate holding a religious text dictating intolerance ought, on Locke's principles, to coerce away. It could even be a Christian magistrate if, as Locke states, "every one's philosophy regulates every one's interpretation of the word of God."101 Here we have an instructive spectacle: a foundation threatening the views it is supposed to support.) In The Reasonableness of Christianity, Locke again takes miracles to be the foundation of reasoned assent to Christianity; there he also interprets the Testaments. He finds that "immortality and bliss belong to the righteous," though the slightest sin warrants damnation. Yet God supplements that impossibly demanding law of works with the law of faith, by which "faith and repentance, i.e. believing Jesus to be the Messiah, and a good life, are the indispensable conditions . . . to be performed by all those who would obtain eternal life." 102

No theologian, I withhold comment on Locke's reading of the

${ }^{98}$ Works IV:96; see too Works IV:281 , 475-482.

${ }^{99}$ Locke, Tbird Letter, in Works VI:402. The point is rehearsed endlessly in all four Letters. Locke sounds Millian tones on toleration in A Second Vindication of the Reasonableness of Cbristianity, in Works VII:376-377.

${ }^{100}$ John Locke, $A$ Second Letter concerning Toleration, in Works VI:82.

${ }^{101}$ John Locke, "An Essay for the Understanding of St. Paul's Epistles," in Works VIII:20. Here again, the medieval problem: what to do with refractory passages in Scripture?

${ }^{102}$ Reasonableness, in Works VII:10, 105. 
Gospel. I do, though, wish to enter the lists on the argument from miracles, for "the most scrupulous or sceptical" may well have objections here. As Locke explicitly notes, we have no firsthand experience of the miracles. ${ }^{103}$ Therefore we may have lots of peccadilloes to launch at the argument. We might say that the disciples were lying, or we might have a story to tell about their motives for (mis)understanding the events the way they did. ${ }^{104}$ More important, we might wonder whether God takes a positive interest in human affairs and is willing to intervene in them; both points are required for the inference from contested extraordinary event to miracle. It's not clear that God cares, or cares enough to act, or would find acting appropriate. Perhaps Locke thought another easy deduction would show his powerful first cause to be a benevolent meddler, but he offers no argument on the point. ${ }^{105}$

The opacity of God's nature, intentions, and interests in our world disables any argument structured like Pascal's wager. Locke could not respond to the kinds of criticisms I've made of his argument by insisting that things are possibly the way he says they are, for it is also possible that there is a spiteful or Manichaean deity who will reward evildoers, or an absurdist deity who will reward all 5'9" brunettes, and so on. Suppose we take seriously the suggestion that we study the world and adopt a reasonable hypothesis. Locke, after all, need not prove that God exists. He need only show that the likelihood is great enough for one who is maximizing utility to be moral. Estimating the odds will be difficult, to say the least. But the problem of evil militates against the hypothesis of a caring, omnipotent God. ${ }^{106}$

${ }^{113}$ See the imagined dialogue between a pagan and a Christian in Locke, Third Letter for Toleration, in Works VI:402.

"The classic exposition is Hume, "Of Miracles," in his Enquiry concerning Human Understanding, in Enquiries, ed. L. A. Selby-Bigge, 3 d ed. rev. by P. H. Nidditch (Oxford: Clarendon, 1978), pp. ro9- I 3 I.

${ }^{105}$ Nor is he fond of mystic intuition. The sentiment of the journal formulation of 18 sep $168 \mathrm{I}$ - "that there is a God, and what that God is, nothing can discover to us, nor judge in us, but natural reason" (King, Life of Jobn Locke, p. 12 3) - remains with him throughout. Again, reason demonstrates God's existence; revelation reveals his commands.

${ }^{106}$ See Mackie's apt discussion in his Miracle of Theism, pp. 150-176. 


\section{LOCKE'S DIVINE POLITICS}

In developing his moral theory, Locke constructs an impressive intellectual edifice. The argument fails at every turn, however, and I can construct no respectable supports for the flaws in its structure. Still, we must consider how Locke's moral theory meshes with the contract arguments of the Treatises. There are puzzles yet in the moral theory, but they are best considered in light of the political doctrine.

\section{An Ungrounded Politics}

Suppose, for a wildly ahistorical moment, that Socrates could have turned from his dialogue with Euthyphro and sweetly enquired of Locke, "So, John, is what God commands good just because he commands it, or does he command some independently specified good?" Locke, having no pantheon of disagreeing deities hanging around, would have been in something of a fix. I wish to articulate that fix as clearly as I can, for it lies at the heart of Locke's prescriptive arguments. Socrates's question would strain the limits of Locke's patience and perhaps of his comprehension: "Whoever sincerely acknowledges any law to be the law of God, cannot fail to acknowledge also, that it hath all that reason and ground that a just and wise law ought to have; and will easily persuade himself to forbear raising such questions and scruples about it." 107 What God commands is morality, in this view, and that's that. This dismissal may well seem persuasive as far as our practice goes. ${ }^{108}$ For understanding the tenor of Locke's political theory, though, we must persuade ourselves to raise just these questions, to push past the easy identification of God's will and morality.

On the one hand, Locke might believe that whatever God

${ }^{107}$ Works IV:188. The remark is in a few pages nestled within the Stillingfleet controversy, apparently addressed to Thomas Burnet's anonymously published Remarks upon an Essay concerning bumane understanding (London, I 697).

${ }^{108}$ For that reason, it seems silly instantly to throw out Locke's moral theory as a violation of Hume's dictum on is/ought, as does W. von Leyden, "John Locke and Natural Law," Pbilosopby 31 (January 1956): 31 (reprinted in Schochet, Life, Liberty, and Property, p. 2 I). Besides, is/ought, like any other interesting philosophical thesis, is deeply problematic, and needs to be argued for, not produced like a trump card. 
commands is morality, just because God commands it. Here morality would be a large-scale system of prudence. Selfish inclinations would be checked by long-term self-interest. Pleasure would be maximized by responding to the allure of heaven and the repulsion of hell, by following whatever rules God happened to lay down for entrance to heaven. ${ }^{109}$ We may be inclined to dismiss such a scheme as having nothing to do with morality; but we have read Kant, or come under his influence, and Locke hadn't. Certainly more classical conceptions of morality or virtue are not wrapped in Kantian paper, and indeed it is devilishly difficult to try to understand them in that way. ${ }^{110}$

On the other hand, Locke may intend divine command to supply sanctions for being moral. In this view, morality would exist independent of God's will, but human beings, being fervid pleasure-seekers, would not pay much heed to it for itself. God, observing this sorry state of affairs, would raise the stakes, and his "unspeakable rewards and punishments" would bring human beings into line.

Locke sometimes sounds as though he adopts the first view. Most dramatically, he refers in passing to "the arbitrary Will and good Pleasure of the Wise Architect"- surely a concession that God may command as whimsically as he likes?"' But a gentle reminder from the Oxford English Dictionary is in order. Arbitrary,

${ }^{109}$ Recall that repentance for Locke is not simply a momentary mental state, but means rather "an hearty sorrow for our past misdeeds, and a sincere resolution and endeavour, to the utmost of our power, to conform all our actions to the law of God. So that repentance does not consist in one single act of sorrow . . . but in 'doing works for repentance'" (Reasonableness, in Works VII: I05).

Does the last of the Essays on the Law of Nature reject this view outright? The argument there is that "each man's personal interest is not the basis of natural law" (Law, p. 207). But it's eminently plausible that Locke means here our worldly interests.

"10Terence Irwin, Plato's Moral Theory,(Oxford: Clarendon, 1977), is a beautifully executed study of a very different attempt to reconcile self-interest and morality. See generally Philippa Foot's superb Virtues and Vices and Other Essays in Moral Philosopby (Berkeley: University of California Press, 1978); and G. E. M. Anscombe's equally superb “Modern Moral Philosophy," Pbilosophy 33 (January 1958): I-19, reprinted in The 1s-Ought Question, ed. W. D. Hudson (New York: St. Martin's Press, 1969). And see Alasdair MacIntyre, After Virtue (Notre Dame, Ind.: University of Notre Dame Press, 198I).

${ }^{\prime \prime}$ Essay, p. 560. 
in a now obsolete usage, means simply "to be decided by one's liking" or, in a legal sense, "relating to, or dependent on, the discretion of an arbiter, arbitrator, or other legally-recognized authority." It need not mean, as we now commonly take it to, capricious or tyrannical. (An etymological guess: repeated experiences of how authorities act are now gloomily reflected in the meaning of the word.) Elsewhere, Locke suggests that "the belief of a God" is "the foundation of all religion and genuine morality," implying that only phony moralities stand without God. ${ }^{12}$

The weight of textual evidence, however, seems to support the second view: God supplies sanctions to a logically prior morality. Take such dictums as "to give a man a full knowledge of true morality I should send him to no other book but the New Testament." 113 Or consider Locke's talk of "the perfections that are in God [as] necessary and unchangeable," "that unchangeably just, wise, good, and all-powerful Being." 114 The only straightforward way of understanding this talk is that God is being measured against an external standard, that of morality. 115 Finally, there are some cryptic comments that make sense only on this reading: "Virtue, as in its obligation it is the will of God, discovered by natural reason, and thus has the force of a law; so in the matter of it, it is nothing else but doing of good, either to oneself or others: and the contrary hereunto, vice, is nothing else but doing of harm." 116 I take it Locke means that virtue and vice

${ }^{112}$ Works IV:53. See too Education, pp. 1 55- I 56; "Of Study," in Axtell, Educational Writings, p. 420; Law, p. I09; Essay, p. 720.

"113"Some Thoughts Concerning Reading and Study for a Gentleman, 1703," in Axtell, Educational Writings, p. 400; also "Of Study," in Axtell, p. 409.

${ }_{114 *}$ An Examination of P. Malebranche's Opinion of Seeing All Things in God," in Works IX:2 52 ; "Defence of Mr. Locke's Opinion concerning Personal Identity," in Works III:195-196. See too King, Life of Jobn Locke, p. 22; Law, p. I 2 I; Essay, P. 356; Reasonableness, in Works VII: I I 2; A Vindication of the Reasonableness of Christianity, in Works VII:356.

${ }^{115}$ Note here the line of criticism in Richard Price, A Review of the Principal Questions in Morals, ed. D. D. Raphael (Oxford: Clarendon, 1974), p. 43, excerpted in British Moralists, ed. D. D. Raphael, 2 vols. (Oxford: Clarendon, 1969), II: I 43; also in L. A. Selby-Bigge's edition of the Moralists, 2 vols. (Oxford, I 897), II: 123.

"16"Common-place Book," I66 I, in King, Life of Jobn Locke, p. 292. See too 
are (the circularity is only verbal) doing good and doing harm. Divine command provides the incentive to adopt the life of virtue. ${ }^{117}$ Entirely comprehensible now is Locke's delightful thumbnail sketch of the history of moral philosophy, worth quoting at length:

The philosophers, indeed, showed the beauty of virtue; they set her off so, as drew men's eyes and approbation to her; but leaving her unendowed, very few were willing to espouse her. The generality could not refuse her their esteem and commendation; but still turned their backs on her, and forsook her, as a match not for their turn. But now there being put into the scales on her side, "an exceeding and immortal weight of glory," interest is come about to her, and virtue now is visibly the most enriching purchase, and by much the best bargain. That she is the perfection and excellency of our nature; that she is herself a reward, and will recommend our names to future ages, is not all that can be said of her. It is not strange that the learned heathens satisfied not many with such airy commendations. It has another relish and efficacy to persuade men, that if they live well here, they shall be happy hereafter. Open their eyes upon the endless, unspeakable joys of another life, and their hearts will find something solid and powerful to move them. . . . Upon this foundation, and upon this only, morality stands firm, and may defy all competition. ${ }^{118}$

Adopting this view resolves another paradox in Locke. Locke could refer to "innocent pagans, strict observers of what is right, and in no way offending against good morals and the civil law"; ${ }^{119}$ yet in the same text he insists that "those who deny the

Reasonableness, in Works VII:I44; Essay, p. 69; "Of Ethics in General," in King, Life of Jobn Locke, p. 3 1 2; Tracts II pp. 222-223.

${ }^{117}$ Nor is this distinction an idiosyncratic invention of Locke. For example, William Paley, The Principles of Moral and Political Pbilosopby, in Raphael, Moralists II:257-260, in Selby-Bigge, Moralists II:357-360, employs just the same distinction, and is plausibly understood only as making a claim about why we do and should follow an independently good rule.

${ }^{118}$ Reasonableness, in Works VII:I 50- I $5 \mathrm{I}$. Two other provocative passages: Second Vindication of the Reasonableness of Cbristianity, in Works VII:229; Law, p. 20I. Locke's claim about ancient moral theory is surprising: compare the myth of Er, or Scipio's Dream.

${ }^{119}$ Letter, p. I I 3 . 
existence of the Deity are not to be tolerated at all," going on to explain, "Promises, covenants, and oaths, which are the bonds of human society, can have no hold upon or sanctity for an atheist; for the taking away of God, even only in thought, dissolves all." ${ }^{120}$ Heathens and atheists may correctly recognize the morality of keeping compacts, but they cannot be counted on to follow the rule, because they do not believe in the weighty sanctions of an afterlife. The allure of worldly pleasures may attract their attention; unendowed virtue, a poor purchase, may stand spurned.

Now, neither answer to Socrates's query seems quite satisfactory. If whatever God commands is good, we seem to be the victims of a morality tossed down at us, unhinged from our interests in the world. If God commands some independently specified good, the appeal to God in the first place seems superfluous: we might as well argue directly from that independent good. Locke in the end refuses to impale himself on either horn of Euthyphro's dilemma. Instead, he works out an intermediate position that suggests that divine-command theories of ethics have more resources than we tend to think.

It will prove useful here to deploy Locke's distinction between primary and secondary qualities. Whether we take his corpuscularian hypothesis as scientific or epistemological, the distinction is clear. Primary qualities exist on their own; secondary qualities depend for their existence on primary qualities. For example, color, in Locke's view, is not really in the objects we see. Instead, it is a secondary quality, a power the objects have, given their primary qualities, to make us experience what we call color. ${ }^{121}$ Suppose we say, then, that primary moral relations ex-

${ }^{120}$ Letter, p. 135. Locke rails against atheism and demands its exclusion from "all sober and civil society" in $A$ Vindication of the Reasonableness of Cbristianity, in Works VII: 16 r. See too The Fundamental Constitutions of Carolina, in Works X: articles XCV, CI, pp. 193, 195. The exclusion of Roman Catholics from liberal tolerance (Letter, pp. 131-135) is in part on different grounds; they have divided political loyalty. But Locke strikes familiar notes in worrying that they believe the Church "can acquit them of all perfidy and perjury" "Letter to S.H." in Tracts, pp. 243-244). See generally on morality and religion Locke's journal for 8 feb i677, in King, Life of Jobn Locke, p. 88; Law, pp. 173, 109.

${ }^{121}$ See generally Essay, pp. 1 34-1 43, 300-303, 535-536, 544-547. 
ist independently of God, while secondary moral relations depend on God and on primary relations. Locke suggests one decisively significant primary moral relation: "God has created us out of nothing and, if He pleases, will reduce us again to nothing: we are, therefore, subject to Him in perfect justice and by utmost necessity." 122 The utmost necessity is nothing new: again Locke invites us to cower before the terrif ying prospect of eternal punishment. Yet the bond is also one of perfect justice because of a strong obligation of gratitude. Locke says nothing here about God's instructing us that it is just to submit to him. A more plausible reading of this passage is that there is a general moral principle dictating obedience to or consideration for one's maker. The justification of that principle does not turn on God. He is simply one maker to whom it applies. Note the difference between this reason for obeying and the suggestion that it is in one's interest to do so.

This primary moral relation introduces moral reasons for our obeying God's commands. Since God created us, we are fairly beholden to his wishes. That moral relation should splash over into the wishes themselves and lend them a distinctively moral aura. Should God command what Locke would elsewhere call things indifferent, things not already vested with moral significance (the prescribed manner of worship in the Testaments is a likely candidate), those things would emerge as secondary moral relations. Without either God's commands or the moral principle of responding to a creator, the manner of worship would be morally irrelevant. Given the commands and the principle, it takes on moral significance.

The structure of this argument would allow Locke to defuse Socrates's query. Goodness is not some indivisible lump, so we need not accept the terms of the Euthyphro dilemma. Instead, we can say that some moral principles hold regardless of God, while others depend on him. We might still say that, for Locke, what God commands is good because he commands it. But now we need to lend emphasis to "he," in a way that alters the mean-

${ }^{122} L a w$, p. 187; also pp. 153-154, 183; Essay, p. 651. See David Gauthier, "Why Ought One Obey God? Reflections on Hobbes and Locke," Canadian Journal of Pbilosopby 7 (September 1977): 425-446. 


\section{LOCKE'S DIVINE POLITICS}

ing of the phrase. God commands rightly, not as an ineffable brooding omnipresence, but as our creator.

How, then, can we link this moral theory to the political theory? Recall first where we left Locke's argument for our obligation to obey the law. I sought an account of why consent, even consent as minimal as residence, generates an obligation. Locke could defend that claim by casting it either as a primary moral relation or as a secondary one. Oddly, he seems to cast it both ways.

First, he suggests that we view consent's obliging powers as a primary moral rule: "Grants, Promises, and Oaths are Bonds that hold the Almighty." 123 Then, however, we still need a story about why consent obliges, and here Locke is singularly reticent. "That Men should keep their compacts, is certainly a great and undeniable Rule in Morality," he proclaims. Yet on the very same page, he declares with as much bravado, "there cannot any one moral Rule be propos'd, whereof a Man may not justly demand a Reason"; ${ }^{124}$ so in his view our question is a sensible one. If we have here a primary rule, Locke nowhere provides a justification for it. Such a justification would yield an account of Locke's liberalism not completely wrapped up in religion; it would allow us to bypass his divine-command theory of ethics. Yet no such account is forthcoming from Locke's texts. ${ }^{125}$

Second, Locke suggests that we view consent's obliging power as a secondary moral rule. As to "things not comprehended in" God's will, he writes, "Man is naturally free, but yet so much master of his own liberty, that he may by compact convey it over to another and invest him with a power over his actions, there being no law of God forbidding a man to dispose of his liberty

${ }^{123}$ Treatises II §195 p. 414; also Treatises I §6 p. 162.

${ }^{124}$ Essay, p. 68.

${ }^{125}$ Compare Dunn, Political Thought, p. 127 . I would modify Dunn's claim that Locke's politics is religious through and through only by adding that it does have conceptual working room for a fairly secular approach. But Locke seems uninterested in filling that room.

Dunn, on the other hand, refuses to pursue the conceptual issues, instead repeatedly dismissing Locke. Note Political Tbought, pp. xin., 2 I, 92, 94-95, 163 , 22 I; Dunn, "Justice and the Interpretation of Locke's Political Theory," Political Studies I 8 (February 1968): 8on. 
and obey another. But on the other side, there being a law of God enforcing fidelity and truth in all lawful contracts, it obliges him after such a resignation and agreement to submit." 126 A subject consents to political authority. By itself, the action is uninteresting; but it is vested with moral significance by God's command of fidelity. Accepting this account of consent and obligation would mean placing Locke firmly in the camp of Christian political theorists. It would mean that his liberalism could not be adequately explicated without extensive appeals to God and scripture. We should not be surprised at this possibility. The more typical early view of Locke is that instead of ascending from the consent of the people, political authority descends from God: "Indirectly and by delegated power the will of any other superior is binding, be it that of a king or a parent, to whom we are subject by the will of God. All that dominion which the rest of law-makers exercise over others, both the right of legislation and the right to impose an obligation to obey, they borrow from God alone, and we are bound to obey them because God willed thus, and commanded thus, so that by complying with them we also obey God." ${ }^{27}$ Whether or not Locke appeals to consent, an account of the obligation to obey the law hanging on his arguments on pleasure, God, and revelation will not do, for those arguments are deeply flawed.

In the end, then, Locke has no satisfactory account of why consent obliges. Consider next his account of legitimacy. Here I sought an account of why the interests of all rational creatures are served best by the liberal state. We have learned that for Locke rationality consists in maximizing pleasure and minimizing pain. But the issue does not devolve to whether or not a liberal society promises lots of pleasure for one and all in this world. Locke insists that the pleasures and pains of the next world outweigh any that this world has to offer. He needs, then, to show how liberalism falls out of the Testaments, for they are our source of knowledge of God's will. (Liberalism in this ac-

${ }^{126}$ Tracts I pp. I 24- I 25.

${ }^{127}$ Law, p. 187; also Tracts II p. 226. I borrow the heuristic distinction between ascending and descending views from Walter Ullmann, Medieval Political Thought (Harmondsworth: Penguin, 1975). 
count would lack primary moral significance.) Locke nowhere even begins that effort. (A rumination on the Straussian ef fort to transform Locke into Hobbes: here Locke needs to imitate Hobbes's fabulous attempt to derive his politics from scripture, but he does not budge in that direction. Locke's expressed attitude toward Hobbes is diffidence. ${ }^{128}$ )

Alternatively, Locke could proffer some primary moral rule(s) leaving liberalism triumphant. Here again there might be principles independent of God's will that would play into the decisions of rational agents. For example, suppose it were wrong to violate a liberal set of rights, and suppose again that God buttressed that primary rule with the sanctions of the afterlife. Then Locke could offer an account of liberalism not wholly ensnared in religion. Nowhere in his writings, though, does he proceed along these lines.

I conclude that if we pursue the argument of the Treatises, we are led farther and farther away from politics. We find ourselves unraveling a tangle of ideas about pleasure, God, and revelation. Locke intends his moral theory to serve as a foundation, but it fails strikingly to support or flesh out his political theory. Like any other foundational structure, Locke's political theory is a house of cards. Should any of the props supporting it be even slightly faulty, the whole structure collapses. But no single prop of this house needs minor adjustment or repair. Instead, major renovation is required.

Perhaps, though, a foundational theory with a far more economical structure will succeed. The modern reader will take Locke's views on pleasure and pain more seriously than his views on religion. And after all, we have a very different theory about the maximization of pleasure on hand, one that proudly disclaims theological commitments and seems perfectly at home in a bureaucratic, scientific world. Accordingly, I now turn to utilitarianism.

${ }^{128}$ Works IV:477; Second Vindication of the Reasonableness of Christianity, in Works VII:420-42 I. See too Locke, "Of Study," in Axtell, Educational Writings, p. 417; Essay, p. 68. 